\title{
Response of Sunflower to Nitrogen Fertilization and Plant Density in Sandy Soils
}

\author{
Hafiz, S. I. ; G. M. Yakout"; M. I. I. Khalii"* and W. E. Sh. M. M. Abo-Eweisha* \\ * Agron. Dept. Fac. Agric. Suez Canal Univ., Ismailia, Egypt \\ **Agric. Botany Dept. Fac. Agric. Suez Canal Univ., Ismailia, Egypt
}

\section{Received: $3 / 6 / 2014$}

\begin{abstract}
Two field experiments were conducted during 2012 and 2013 seasons at the Agricultural Experimental Farm of Suez Canal University at Ismailia in the first season and El-Manayf district in the second season in Ismailia Governorate to study the effect of four nitrogen fertilization treatments namely 25, 45, 65 and $25 \mathrm{Kg} \mathrm{N} /$ fad plus biofertilizer (Cerealin) as well as three plant densities namely 46666, 35000 and 28000 plants/fad resulted by sowing sunflower in ridges $60 \mathrm{~cm}$ in width and hill spacings 15, 20 and $25 \mathrm{~cm}$ on sunflower Sakha 53 variety in sandy soils. Increasing nitrogen fertilization up to $65 \mathrm{Kg} \mathrm{N} /$ fad significantly increased all growth characters, yield attributes as well as seed, biological and oil yields/fad. Applying biofertilizer (Cerealin) plus $25 \mathrm{Kg} \mathrm{N} /$ fad significantly surpassed $25 \mathrm{Kg}$ $\mathrm{N} /$ fad alone in the above characters. Decreasing hill spacing up to $15 \mathrm{~cm}$ significantly increased seed, biological and oil yields/fad. There was significant interaction between nitrogen fertilization and plant density on seed, biological and oil yields/fad. The highest seed, biological and oil yields/fad were obtained by adding $65 \mathrm{Kg} \mathrm{N} /$ fad under dense planting of 46666 plants/fad.
\end{abstract}

Keywords: Sunflower - Nitrogen - Biofertilization - Plant density

\section{INTRODUCTION}

Sunflower (Helianthus annuus L.) is one of the most important sources of edible oil in the world. In Egypt the total production of edible oils is about $5 \%$ of the consumption. Sunflower is a promising oil crop for narrowing oil deficiency gap due to its adaptability to wide variation of soils and climatic conditions as well as the high oil content in its seeds. Increasing the area devoted to sunflower in the Nile valley is very difficult due to great competition from other summer cash crops and its lower net income compared to these crops such as cotton, rice and corn. Therefore, expanding area under sunflower should be taken in newly reclaimed sandy soils which facing many problems like low fertility especially nitrogen, poverty and high loss of nutrients by leaching.

The nitrogen deficiency in Egyptian sandy soils is one of the most limiting factors for sunflower production. Under these conditions there is great importance to estimate the optimum requirements of nitrogen fertilization

The favorable effects of applying mineral nitrogen fertilization on growth, yield attributes, seed yield and quality of sunflower were reported by Zeiton (1992), Geweifel et al., (1997), Metwally (1997), El-Kalla et al., (1998), Abou-Khadrah et al., (2000), Basha (2000), Abd El-samie et al., (2002), Abou-Khadrah et al., (2002), Ibrahim et al., (2003), Khalil (2003), Mohamed (2003), Ali et al., (2004), Al-Thabet (2006), Ibrahim et al., (2006), El-Sarag (2007), Gholinezhad et al., (2009), Hassan (2010), Sala et al., (2010), Soleimanzadeh et al., (2010), Yasein (2010), Ali et al., (2012), Namvar et al., (2012), Wabekwa et al., (2012), Ali and Noorka (2013) and Sincik et al., (2013).

Undoubtedly application of $\mathrm{N}$ chemical fertilizers not only raises the cost of production but also causes environmental pollution. Hence using bio nitrogen fertilizers may avoid these problems and increase the crop productivity. The beneficial effects of nitrogen biofertilizers (nitrogen fixing bacteria) on sunflower crop were demonstrated by Keshta and El-Kholy (1999)
Mohamed (2003), Aowad and Mohamed (2009), Hassan (2010), Akbari et al., (2011), Namvar et al., (2012) and Patra et al., (2013).

Cultivating sunflower in sandy soils should be preceded by accurate adopting of its agronomic practices on such lands especially determing the optimum plant density. Many investigators studied the effect of plant density on sunflower crop, Zeiton (1992), Sharief and Said (1993), Abd El-Samie et al., (1995), Sarhan (1995), Allam and Galal (1996), Metwally (1997), Basha (2000), Malik et al., (2001), Bassal (2003), Olowe (2005), Beg et al., (2007), Hassan (2007), Gholinezhad et al., (2009), El-Naim and Ahmed (2010), Mehrpouyan et al., (2010), Yasein (2010), Bukhsh et al., (2011), Al-Doori (2012), Ali et al., (2012) and Namvar et al., (2012) .

The present investigation aimed to study the response of sunflower Sakha 53 variety to mineral and bio nitrogen fertilization as well as plant density in newly reclaimed sandy soils at Ismailia Governorate.

\section{MATERIALS AND METHODS}

Two field experiments were conducted during 2012 and 2013 seasons at the Agricultural Experimental farm of Suez Canal University and El-Manayf district in Ismailia Governorate, respectively to study the effect of nitrogen fertilization and plant density on sunflower (Helianthus annuus L.).

The soil of the experiments was sandy with $\mathrm{pH}$ values of 7.83 and 7.71 and contained 4.59 and $6.83 \mathrm{ppm}$ available $\mathrm{N}, 1.78$ and $1.96 \mathrm{ppm}$ available $\mathrm{P}, 10.22$ and $11.15 \mathrm{ppm}$ available $\mathrm{K}$ and $0.11 \%$ and $0.17 \%$ organic matter in the two seasons, respectively.

Each experiment included 12 treatments, which were the combinations of four nitrogen fertilization treatments and three plant densities.

The experimental design was split plots with four replicates. Four nitrogen fertilization treatments arranged randomly in the main plots, while the three plant densities were allocated at random in sub plots. 
Each experimental sub plot consisted of six ridges, 4 meter in length and $60 \mathrm{~cm}$ in width (plot area was 14.4 $\mathrm{m}^{2}$ ).

Four nitrogen fertilization treatments were 25, 45, 65 and $25 \mathrm{Kg} \mathrm{N} /$ fad plus biofertilizer (Cerealin).

Three plant densities were 46666, 35000 and 28000 plants /fad resulted by sowing sunflower in ridges $60 \mathrm{~cm}$ in width and hill spacings 15, 20 and $25 \mathrm{~cm}$.

The variety used was Sakha 53. Seeds were sown on May 13 and 10 in the first and second seasons, respectively. After 10 days from sowing sunflower plants were thinned to one plant per hill.

Nitrogen in the form of ammonium nitrate $(33.5 \%$ $\mathrm{N})$ at the previous rates was applied at three equal doses, after thinning (10 days from sowing), 25 and 40 days from sowing.

Biofertilizer (Cerealin) contains nitrogen fixing bacteria as a commercial packet was produced by Ministry of Agriculture in Egypt.

The treatment of Cerealin was done by coating seeds with Arab gum and inoculated with Cerealin before sowing immediately.

A basal dose of calcium superphosphate $\left(15.5 \% \mathrm{P}_{2} \mathrm{O}_{5}\right)$ at rate of $200 \mathrm{Kg} / \mathrm{fad}$ was applied at two equal doses. The first dose during soil preparing and the second one at 40 days from sowing.

A basal dose of potassium sulphate $\left(48 \% \mathrm{~K}_{2} \mathrm{O}\right)$ at rate of $75 \mathrm{Kg} /$ fad was applied at three equal doses, after thinning, 25 and 40 days from sowing.

The normal cultural practices for growing sunflower crop at Ismailia Governorate were followed.

After 55 days from sowing, five guarded plants were randomly taken from the second ridge of each sub plot to estimate leaves area per plant $\left(\mathrm{cm}^{2}\right)$ using dry weight method to Rhoads and Bloodworth (1964), leaf area index (LAI) accounted by dividing leaves area per plant on land area occupied by one plant and total dry weight per plant $(\mathrm{g})$.

At harvest time, after 100 days from sowing, samples of ten guarded plants were randomly taken from the two inner ridges in each sub plot to determine plant height $(\mathrm{cm})$, stem diameter $(\mathrm{cm})$ at $30 \mathrm{~cm}$ from surface soil, head diameter $(\mathrm{cm}), 100$-seed weight $(\mathrm{g})$, number of seeds/head, seed weight per head (g).

While seed yield $(\mathrm{Kg} / \mathrm{fad})$ and biological yield (ton/ fad) were estimated from the plants of the three inner ridges in each sub plot and the yields per fad were calculated.

Seed oil percentage was determined by using the Soxhelt continuous extraction apparatus with petroleum ether as an organic solvent according to A.O.A.C. (1975). Oil yield (Kg/ fad) was calculated by multiplying oil percentage and seed yield per fad.

The analysis of variance of split plots design was used according to Snedecor and Cochran (1982). The combined analysis of variance was performed for the data of the two seasons. Means followed by the same alphabetical letters are not statistically different according to Duncan's Multiple Range Test at the 5\% level of significance (Duncan, 1955).

\section{RESULTS AND DISCUSSION}

\section{A -Effect of nitrogen fertilization:-}

Data in Table (1) show that increasing mineral nitrogen fertilizer level from 25 to $65 \mathrm{Kg} \mathrm{N} / \mathrm{fad}$ significantly increased leaves area per plant, leaf area index and total dry weight per plant at 55 days from sowing in 2012 and 2013 seasons as well as their combined average. These results are in harmony with those reported by Abou-Khadrah et al., (2000), Ibrahim et al., (2003), Hassan (2010), Yasein (2010) and Wabekwa et al., (2012).

Adding the high nitrogen level of $65 \mathrm{Kg} \mathrm{N} / \mathrm{fad}$ resulted the highest values of leaves area per plant, leaf area index and total dry weight per plant at 55 days from sowing and it deviated in this respect significantly with the treatment of $25 \mathrm{Kg} \mathrm{N} /$ fad plus biofertilizer (Cerealin) in the two seasons and the combined data except leaves area/plant in 2013 season where the variance was insignificant.

Applying biofertilizer (Cerealin) plus $25 \mathrm{Kg} \mathrm{N} /$ fad surpassed significantly $25 \mathrm{Kg} \mathrm{N} / \mathrm{fad}$ alone in the aforementioned characters and that held true in both seasons and the combined data (Table 1). Similar results were obtained by Shehata and El-Khawas (2003), Aowad and Mohamed (2009) and Mostafa and AboBaker (2010).

It is obvious from Table (2) that stem diameter at harvest increased significantly with applying nitrogen fertilization until $45 \mathrm{Kg} \mathrm{N} /$ fad and further increase in $\mathrm{N}$ rate resulted in no significant increase in the two seasons and over them. Similar results were found by Metwally (1997), Ibrahim et al., (2003) and Yasein (2010).

Adding biofertilizer (Cerealin) with $25 \mathrm{Kg} \mathrm{N} / \mathrm{fad}$ overcome significantly $25 \mathrm{Kg} \mathrm{N} /$ fad alone in stem diameter in 2012 and 2013 seasons as well as the combined data. Confirming results were emphasized by Aowad and Mohamed (2009).

Results in Tables (2 and 3) indicate that plant height, head diameter, seed weight per head and 100-seed weight at harvest were significantly increased with adding nitrogen fertilization up to $65 \mathrm{Kg} \mathrm{N} / \mathrm{fad}$ and that was true in the two seasons and over them. These results are concordant with those found by Ibrahim et al., (2006), El-Sarag (2007), Hassan (2010), Yasein (2010), Ali et al., (2012) and Ali and Noorka (2013) .

Application of biofertilizer (Cerealin) plus $25 \mathrm{Kg}$ $\mathrm{N} /$ fad surpassed significantly $25 \mathrm{Kg} \mathrm{N} /$ fad alone in the aforementioned characters in both seasons and their combined average. Confirming results were recorded by Mohamed (2003), Hassan (2010) and Patra et al., (2013).

Number of seeds per head at harvest was increased gradually by increasing nitrogen fertilization up to 65 $\mathrm{Kg} \mathrm{N} / \mathrm{fad}$, which also overcome the treatment of $25 \mathrm{Kg}$ $\mathrm{N} /$ fad plus biofertilizer (Cerealin), however the difference among the four nitrogen treatments was not great enough to reach the $5 \%$ level of significance in the two seasons and over them except between the high $\mathrm{N}$ level of $65 \mathrm{Kg} \mathrm{N} / \mathrm{fad}$ and $25 \mathrm{Kg} \mathrm{N} / \mathrm{fad}$ in the second season and the combined data (Table 3 ). These findings are in same trend with those found by Zeiton (1992), Geweifel et al., (1997), Abou-Khadrah et al., (2000) and Yasein (2010). 
Data in Table (4) illustrate that seed oil percentage was significantly increased as nitrogen rate decreased up to $25 \mathrm{Kg} \mathrm{N} /$ fad in 2012 and 2013 seasons as well as over them. These resulted were expected since the low nitrogen level resulted smaller seeds (100-seed weight) as shown in Table (3) and this might be on the expense of carbohydrate storage rather than oil which resulted in increasing percentage of the later. Similar findings were obtained by Al-Thabet (2006), Hassan (2010) and Ali et al., (2012).

It is clearly evident from Table (4) that seed, biological and oil yields/fad increased statistically with increasing nitrogen rate up to $65 \mathrm{Kg} \mathrm{N} / \mathrm{fad}$, which also surpassed significantly the treatment of $25 \mathrm{Kg} \mathrm{N} /$ fad plus biofertilizer (Cerealin) in the two seasons and their combined average.

Application of biofertilizer (Cerealin) plus $25 \mathrm{Kg}$ $\mathrm{N} /$ fad induced significant increase in seed, biological and oil yields/fad compared to $25 \mathrm{Kg} \mathrm{N} /$ fad alone and that held true in both seasons and over them (Table 4).

The relative increases in seed yield/fad for applying 65, 45 and $25 \mathrm{Kg} \mathrm{N} /$ fad plus biofertilizer (Cerealin) compared to $25 \mathrm{Kg} \mathrm{N} /$ fad were $37.89 \%, 18.17 \%$ and $21.14 \%$, respectively in the combined data (Table 4).

The favorable effect of nitrogen application on seed yield per fad might be due to that nitrogen is the most important essential nutrient in plant nutrition, it is a constituent of a large number of necessary organic compounds such as amino acids, proteins, coenzymes, nucleic acids, ribosomes, chlorophyll, cytochrome and some vitamins (Marschner, 1986). Moreover N enhances photosynthesis rate and metabolic processes which reflected on encouraging leaves area per plant and leaf area index which increase the amount of light energy intercepted by plants, consequently increment the amount of metabolites synthesized in the leaves and partitioned to fruiting organs which reflected favorably on head diameter, 100-seed weight, number of seeds/head and seed weight per head, ultimately increased seed yield per fad.

Many investigators stated that increasing nitrogen fertilization increase seed yield/fad, Zeiton (1992), Abou-Khadrah et al., (2002), Khalil (2003), Mohamed (2003) and Hassan (2010) up to $45 \mathrm{Kg} \mathrm{N} / \mathrm{fad}$, Metwally (1997), Abd El-Samie et al., (2002), Ibrahim et al., (2003) and El-Sarag (2007) up to $60 \mathrm{Kg} \mathrm{N} / \mathrm{fad,} \mathrm{El-Kalla}$ et al., (1998) up to $70 \mathrm{Kg} \mathrm{N} / \mathrm{fad}$, Geweifel et al., (1997), Basha (2000) and Ibrahim et al., (2006) up to $90 \mathrm{Kg}$ $\mathrm{N} /$ fad and Sala et al., (2010) up to $200 \mathrm{Kg} \mathrm{N} / \mathrm{ha}$.

The observed benefits on sunflower inoculated by biofertilizer (Cerealin) which contains nitrogen fixing bacteria seem to be due to the supply of higher amount of nitrogen by bacteria. Also plant growth regulators such as Auxins, Gibberellines and Cytokinins produced by these bacteria which promote good root development, hence increase nutrients uptake and water as well as photosynthesis rate and dry matter accumulation which enhance plant growth characters i.e. plant height, total dry weight of plant, leaves area/plant, leaf area index and stem diameter which reflected on yield attributes such as number and weight of seeds/head and 100-seed weight finally increase seed yield per fad.
Many investigators stated that applying biofertilizers increased seed yield per fad, Keshta and El-Kholy (1999), Mohamed (2003), Aowad and Mohamed (2009), Hassan (2010) and Patra et al., (2013).

The increase in biological yield per fad by adding nitrogen fertilization might be due to that $\mathrm{N}$ encourages cell division, the meristemic activity, plant height, leaves area per plant, leaf area index, photosynthesis rate and enzymes activity which increase the amount of metabolites synthesized by plant, in turn resulted in higher dry matter accumulated in the different parts of plant such as stem, leaves, head and seeds, hence increment biological yield per fad.

These results are in conformity with those reported by Geweifel et al., (1997) who demonstrated that biological yield per fad was increased by increasing nitrogen fertilization up to $90 \mathrm{Kg} \mathrm{N} / \mathrm{fad}$, Ibrahim et al., (2003) up to $60 \mathrm{Kg} \mathrm{N} / \mathrm{fad}$, Ali et al., (2004) up to 200 $\mathrm{Kg} \mathrm{N} / \mathrm{ha}$, Gholinezhad et al., (2009) up to $220 \mathrm{Kg} \mathrm{N} / \mathrm{ha}$, Soleimanzadeh et al., (2010) up to $150 \mathrm{Kg} \mathrm{N} / \mathrm{ha}$, Yasein (2010) up to $120 \mathrm{Kg} \mathrm{N} / \mathrm{fad,} \mathrm{Namvar} \mathrm{et} \mathrm{al.,} \mathrm{(2012)} \mathrm{up} \mathrm{to}$ $150 \mathrm{Kg} \mathrm{N} / \mathrm{ha}$ and Wabekwa et al., (2012) up to $90 \mathrm{Kg}$ $\mathrm{N} / \mathrm{ha}$.

The increase in oil yield per fad by increasing nitrogen rate could be mainly due to the increase in seed yield/fad regardless the negative effect of that on seed oil percentage.

Several researchers revealed that oil yield/fad was increased by increasing nitrogen fertilization, Basha (2000), Mohamed (2003), Al-Thabet (2006), Hassan (2010), Yasein (2010) and Sincik et al., (2013).

Many investigators concluded that biofertilization increased oil yield/fad of sunflower, Mohamed (2003), Aowad and Mohamed (2009), Hassan (2010) and Akbari et al., (2011).

\section{B- Effect of plant density:-}

Data in Table (1) illustrate that increasing plant population density from 28000 to 35000 and 46666 plants/fad by decreasing planting distance between hills from 25 to 20 and $15 \mathrm{~cm}$, respectively significantly increased leaf area index at 55 days from sowing in both seasons and over them. Similar results were found by Sharief and Said (1993), Gholinezhad et al., (2009) and El-Naim and Ahmed (2010).

Results in Table (1) show that leaves area per plant and total dry weight per plant at 55 days from sowing were significantly increased as hill spacing broaden up to $25 \mathrm{~cm}$ and that was true during 2012 and 2013 seasons as well as their combined average. Confirming findings were recorded by Malik et al., (2001), Hassan (2007), Yasein (2010) and Al-Doori (2012).

Plant height at harvest increased significantly as planting distance was decreased from 25 to $20 \mathrm{~cm}$, however further decrease in hill spacing gave insignificant increase in the two seasons and over them (Table2). These results might be due to higher competition among plants for light in dense plant population, resulting in elongation of internodes and in turn gave taller plants. Similar results were obtained by Bassal (2003), Bukhsh et al., (2011) and Namvar et al., (2012). 
Table (1): Effect of nitrogen fertilization and plant density on leaves area per plant, leaf area index and total dry weight per plant at 55 days from sowing.

\begin{tabular}{|c|c|c|c|c|c|c|c|c|c|}
\hline \multirow{2}{*}{ Treatments } & \multicolumn{3}{|c|}{ Leaves area per plant $\left(\mathrm{cm}^{2}\right)$} & \multicolumn{3}{|c|}{ Leaf area index } & \multicolumn{3}{|c|}{ Total dry weight per plant (g) } \\
\hline & 2012 & 2013 & Comb. & 2012 & 2013 & Comb. & 2012 & 2013 & Comb. \\
\hline \multicolumn{10}{|c|}{ Nitrogen fertilization (Kg/fad) } \\
\hline $25 \mathrm{Kg} / \mathrm{fad}$ & $1433.00 \mathrm{C}$ & $1554.00 \mathrm{C}$ & $1493.49 \mathrm{C}$ & $1.230 \mathrm{C}$ & $1.333 \mathrm{D}$ & $1.281 \mathrm{D}$ & $37.00 \mathrm{C}$ & $39.34 \mathrm{C}$ & $38.16 \mathrm{C}$ \\
\hline $45 \mathrm{Kg} / \mathrm{fad}$ & $1679.00 \mathrm{~B}$ & $1777.00 \mathrm{~B}$ & $1727.99 \mathrm{~B}$ & $1.448 \mathrm{~B}$ & $1.533 \mathrm{C}$ & $1.490 \mathrm{C}$ & $43.50 \mathrm{~B}$ & $46.53 \mathrm{~B}$ & $45.00 \mathrm{~B}$ \\
\hline $65 \mathrm{Kg} / \mathrm{fad}$ & $1892.33 \mathrm{~A}$ & $2001.66 \mathrm{~A}$ & $1946.99 \mathrm{~A}$ & $1.636 \mathrm{~A}$ & $1.729 \mathrm{~A}$ & $1.682 \mathrm{~A}$ & $50.06 \mathrm{~A}$ & $52.32 \mathrm{~A}$ & $51.19 \mathrm{~A}$ \\
\hline $\begin{array}{l}25 \mathrm{Kg} / \mathrm{fad} \\
\text { plus Cerealin }\end{array}$ & $1769.33 \mathrm{~B}$ & $1892.00 \mathrm{~A}$ & $1830.66 \mathrm{~B}$ & $1.524 \mathrm{~B}$ & $1.629 \mathrm{~B}$ & $1.576 \mathrm{~B}$ & $45.66 \mathrm{~B}$ & $47.37 \mathrm{~B}$ & $46.51 \mathrm{~B}$ \\
\hline F.test & $*$ & * & $*$ & $*$ & $*$ & $*$ & $*$ & $*$ & $*$ \\
\hline \multicolumn{10}{|c|}{ Hill spacing (Plants/fad) } \\
\hline $15 \mathrm{~cm}(46666)$ & $1601.16 \mathrm{C}$ & $1701.41 \mathrm{C}$ & $1651.28 \mathrm{C}$ & $1.778 \mathrm{~A}$ & $1.890 \mathrm{~A}$ & $1.833 \mathrm{~A}$ & $41.21 \mathrm{C}$ & $43.25 \mathrm{C}$ & $42.23 \mathrm{C}$ \\
\hline $20 \mathrm{~cm}(35000)$ & $1697.41 \mathrm{~B}$ & 1809.66 B & $1753.53 \mathrm{~B}$ & $1.414 \mathrm{~B}$ & $1.507 \mathrm{~B}$ & $1.460 \mathrm{~B}$ & $43.84 \mathrm{~B}$ & $46.17 \mathrm{~B}$ & $45.00 \mathrm{~B}$ \\
\hline $25 \mathrm{~cm}(28000)$ & $1781.66 \mathrm{~A}$ & $1907.41 \mathrm{~A}$ & $1844.53 \mathrm{~A}$ & $1.187 \mathrm{C}$ & $1.271 \mathrm{C}$ & $1.229 \mathrm{C}$ & $47.11 \mathrm{~A}$ & $49.75 \mathrm{~A}$ & $48.43 \mathrm{~A}$ \\
\hline F.test & $*$ & $*$ & $*$ & $*$ & $*$ & $*$ & $*$ & * & $*$ \\
\hline $\mathbf{N x D}$ & $*$ & $*$ & $*$ & $*$ & $*$ & $*$ & $*$ & $*$ & $*$ \\
\hline
\end{tabular}

Increasing hill spacing from 15 to $20 \mathrm{~cm}$ significantly increased stem diameter at harvest, then any increase in planting distance resulted no significant increase and that held true in the two seasons and over them (Table 2). Confirming results were found by Metwally (1997), Beg et al., (2007), Yasein (2010) and Namvar et al., (2012).

Decreasing plant density up to 28000 plants/fad through increasing planting distance from 15 to 20 and $25 \mathrm{~cm}$ produced significant increases in head diameter of sunflower in the two growing seasons and over them, except that between 15 and $20 \mathrm{~cm}$ in the first season where the difference was not great enough to reach the $5 \%$ level of significance (Table 2). These results agree with those found by Sarhan (1995), Basha (2000) and Ali et al., (2012).

The data presented in Table (3) reveal that increasing hill spacing from 15 to 20 and $25 \mathrm{~cm}$ produced significant increases in number of seeds per head, seed weight per head and 100-seed weight and that was true in the two seasons and their combined average. These results might be attributed to the more availability and sufficiency of different growth factors such as space, light, moisture and nutrients, which increase plant growth especially leaves area per plant and photosynthesis rate in turn enhance dry matter accumulation in leaves and partitioned to seeds consequently increase yield components such as number and weight of seeds per head and 100-seed weight. These results are in conformity with those found by Zeiton (1992), Sarhan (1995), Allam and Galal (1996), Metwally (1997), Basha (2000), Yasein (2010), Ali et al., (2012) and Namvar et al., (2012).

It is clearly evident from Table (4) that seed oil percentage was significantly increased by decreasing hill spacing from 25 to $20 \mathrm{~cm}$ in the two seasons and the combined data. The increase in seed oil percentage in dense planting may be due to that plants sown in narrow hill spacing produced light seeds (100-seed weight) as shown in Table (3) and this might be on the expense of carbohydrate storage rather than oil which resulted in incrementing percentage of oil. Similar findings were emphasized by Abd El-Samie et al., (1995), Allam and Galal (1996) and Ali et al., (2012).

Data in Table (4) demonstrate that there were consistent and significant increases in seed, biological and oil yields per fad as plant density was raised up to 46666 plants/fad via decreasing planting distance up to $15 \mathrm{~cm}$ and that held true in both seasons and over them.

The highest plant density of 46666 plants/fad outyielded medium and low densities (35000 and 28000 plants/fad) in seed yield/fad by $11.68 \%$ and $26.77 \%$, respectively in the combined data as given in Table (4).

The positive effect of increasing plant population density on seed and biological yields per fad might be due to that the greater number of sunflower plants per unit land area in narrow hill spacing could compensate the reduction in yield components of the individual plants such as number of seeds per head, 100- seed weight and seed weight per head. It is great importance that the unit land area not the individual plant, produces its maximum yield/fad.

These results are in harmony with those reported by Sarhan (1995), Metwally (1997), Malik et al., (2001), Olowe (2005), Hassan (2007), Gholinezhad et al., (2009), Mehrpouyan et al., (2010), Yasein (2010), Bukhsh et al., (2011) and Namvar et al., (2012).

The increase in oil yield per fad in dense planting could be mainly due to the increase in both seed yield per fad and seed oil percentage in higher plant density.

Several investigators emphasized that oil yield/fad increased by increasing plant density, Zeiton (1992) from 20000 to 46666 plants/fad, Sharief and Said (1993) from 28000 to 56000 plants/fad, Allam and 
Galal (1996) from 24000 to 33600 plants/fad, Mehrpouyan et al., (2010) from 66000 to 110000 plants/ha, Yasein (2010) from 23333 to 28000 plants/fad, Al-Doori (2012) from 41666 to 66666 plants/ha and Namvar et al., (2012) from 8 to 10 plants $/ \mathrm{m}^{2}$.

\section{C-Interaction effect:-}

The combined analysis of variance for the data of the two seasons revealed that there was significant interaction effect between nitrogen fertilization and plant density on seed oil percentage as well as seed, biological and oil yields per fad as shown in Table (5).

The highest seed oil percentage was produced from plants fertilized with low $\mathrm{N}$ rate of $25 \mathrm{Kg} \mathrm{N} /$ fad under the dense planting of 46666 plants/fad .While the lowest one was recorded by adding high $\mathrm{N}$ level of $65 \mathrm{Kg}$ $\mathrm{N} /$ fad under light density of 28000 plants/fad.

The highest seed, biological and oil yields per fad were obtained by plants under dense planting of 46666 plants/fad when high $\mathrm{N}$ rate of $65 \mathrm{Kg} \mathrm{N} / \mathrm{fad}$ was applied. While the lowest one was recorded from plants under thin density of 28000 plants/fad when low $\mathrm{N}$ level of $25 \mathrm{Kg} \mathrm{N} /$ fad was added. Zeiton (1992) reported that the highest seed yield/fad was achieved from plant density 46666 plants/fad and applying $45 \mathrm{Kg} \mathrm{N} / \mathrm{fad}$. Also, Al-Thabet (2006) concluded that the highest seed and oil yields/ha was obtained by application of $200 \mathrm{Kg}$ $\mathrm{N} /$ ha with sowing at $25 \mathrm{~cm}$ between hills. Moreover, Hassan (2007) stated that the highest seed and oil yields/fad were achieved by sowing at $20 \mathrm{~cm}$ hill spacing and applying $60 \mathrm{Kg} \mathrm{N} / \mathrm{fad}$. Gholinezhad et al., (2009) stated that applying the high nitrogen level of $220 \mathrm{Kg} \mathrm{N} / \mathrm{ha}$ under the dense planting of 8.33 plants $/ \mathrm{m}^{2}$ produced the highest biological yield/ha. Namvar et al., (2012) demonstrated that the highest seed, biological and oil yields /ha was gained by adding 150 or $200 \mathrm{Kg}$ $\mathrm{N} /$ ha with 10 plants $/ \mathrm{m}^{2}$.

Table (2): Effect of nitrogen fertilization and plant density on plant height, stem diameter and head diameter at harvest.

\begin{tabular}{|c|c|c|c|c|c|c|c|c|c|}
\hline \multirow{2}{*}{ Treatments } & \multicolumn{3}{|c|}{ Plant height (cm) } & \multicolumn{3}{|c|}{ Stem diameter $(\mathrm{cm})$} & \multicolumn{3}{|c|}{ Head diameter $(\mathrm{cm})$} \\
\hline & 2012 & 2013 & Comb. & 2012 & 2013 & Comb. & 2012 & 2013 & Comb. \\
\hline \multicolumn{10}{|c|}{ Nitrogen fertilization $(\mathrm{Kg} / \mathrm{fad})$} \\
\hline $25 \mathrm{Kg} / \mathrm{fad}$ & $107.00 \mathrm{C}$ & $114.66 \mathrm{C}$ & $110.82 \mathrm{C}$ & $1.476 \mathrm{~B}$ & $1.589 \mathrm{~B}$ & $1.532 \mathrm{~B}$ & $14.76 \mathrm{C}$ & $16.00 \mathrm{C}$ & $15.38 \mathrm{C}$ \\
\hline $45 \mathrm{Kg} / \mathrm{fad}$ & $118.66 \mathrm{~B}$ & $126.33 \mathrm{~B}$ & $122.49 \mathrm{~B}$ & $1.576 \mathrm{~A}$ & $1.712 \mathrm{~A}$ & $1.643 \mathrm{~A}$ & $16.20 \mathrm{~B}$ & $17.72 \mathrm{~B}$ & $16.95 \mathrm{~B}$ \\
\hline $65 \mathrm{Kg} / \mathrm{fad}$ & $129.00 \mathrm{~A}$ & $137.11 \mathrm{~A}$ & $133.05 \mathrm{~A}$ & $1.661 \mathrm{~A}$ & $1.816 \mathrm{~A}$ & $1.738 \mathrm{~A}$ & $17.82 \mathrm{~A}$ & $19.59 \mathrm{~A}$ & $18.70 \mathrm{~A}$ \\
\hline $\begin{array}{l}25 \mathrm{Kg} / \text { fad plus } \\
\text { Cerealin }\end{array}$ & $120.88 \mathrm{~B}$ & $128.00 \mathrm{~B}$ & $124.43 \mathrm{~B}$ & $1.593 \mathrm{~A}$ & $1.727 \mathrm{~A}$ & $1.659 \mathrm{~A}$ & $16.38 \mathrm{~B}$ & $17.84 \mathrm{~B}$ & $17.11 \mathrm{~B}$ \\
\hline F.test & $*$ & $*$ & $*$ & $*$ & $*$ & $*$ & $*$ & $*$ & \\
\hline \multicolumn{10}{|c|}{ Hill spacing (Plants/fad) } \\
\hline $15 \mathrm{~cm}(46666)$ & $123.83 \mathrm{~A}$ & $132.66 \mathrm{~A}$ & $128.24 \mathrm{~A}$ & $1.510 \mathrm{~B}$ & $1.635 \mathrm{~B}$ & $1.572 \mathrm{~B}$ & $15.79 \mathrm{~B}$ & $17.18 \mathrm{C}$ & $16.48 \mathrm{C}$ \\
\hline $20 \mathrm{~cm}(35000)$ & $119.66 \mathrm{~A}$ & $127.66 \mathrm{~A}$ & $123.66 \mathrm{~A}$ & $1.583 \mathrm{~A}$ & $1.719 \mathrm{~A}$ & $1.651 \mathrm{~A}$ & $16.26 \mathrm{~B}$ & $17.79 \mathrm{~B}$ & $17.02 \mathrm{~B}$ \\
\hline $25 \mathrm{~cm}(28000)$ & $113.16 \mathrm{~B}$ & $119.25 \mathrm{~B}$ & $116.20 \mathrm{~B}$ & $1.636 \mathrm{~A}$ & $1.778 \mathrm{~A}$ & $1.706 \mathrm{~A}$ & $16.82 \mathrm{~A}$ & $18.40 \mathrm{~A}$ & $17.61 \mathrm{~A}$ \\
\hline F.test & $*$ & $*$ & $*$ & $*$ & $*$ & $*$ & $*$ & $*$ & $*$ \\
\hline NxD & $*$ & * & $*$ & $*$ & $*$ & $*$ & $*$ & $*$ & $*$ \\
\hline
\end{tabular}

Table (3): Effect of nitrogen fertilization and plant density on number of seeds per head, seed weight per head and 100seed weight at harvest.

\begin{tabular}{|c|c|c|c|c|c|c|c|c|c|}
\hline \multirow{2}{*}{ Treatments } & \multicolumn{3}{|c|}{ Number of seeds per head } & \multicolumn{3}{|c|}{ Seed weight per head (g) } & \multicolumn{3}{|c|}{ 100-seed weight (g) } \\
\hline & 2012 & 2013 & Comb. & 2012 & 2013 & Comb. & 2012 & 2013 & Comb. \\
\hline \multicolumn{10}{|c|}{ Nitrogen fertilization $(\mathrm{Kg} / \mathrm{fad})$} \\
\hline $25 \mathrm{Kg} / \mathrm{fad}$ & $929.77 \mathrm{~A}$ & $986.88 \mathrm{~B}$ & $958.33 \mathrm{~B}$ & $55.94 \mathrm{C}$ & $61.99 \mathrm{C}$ & $58.96 \mathrm{C}$ & $5.87 \mathrm{C}$ & $6.04 \mathrm{C}$ & $5.95 \mathrm{C}$ \\
\hline $45 \mathrm{Kg} / \mathrm{fad}$ & $942.44 \mathrm{~A}$ & $998.44 \mathrm{AB}$ & $970.44 \mathrm{AB}$ & $62.40 \mathrm{~B}$ & $68.52 \mathrm{~B}$ & $65.46 \mathrm{~B}$ & $6.64 \mathrm{~B}$ & $6.90 \mathrm{~B}$ & $6.77 \mathrm{~B}$ \\
\hline $65 \mathrm{Kg} / \mathrm{fad}$ & $965.44 \mathrm{~A}$ & $1041.11 \mathrm{~A}$ & $1003.27 \mathrm{~A}$ & $69.88 \mathrm{~A}$ & $78.20 \mathrm{~A}$ & $74.03 \mathrm{~A}$ & $7.30 \mathrm{~A}$ & $7.59 \mathrm{~A}$ & $7.44 \mathrm{~A}$ \\
\hline $\begin{array}{l}25 \mathrm{Kg} / \text { fad plus } \\
\text { Cerealin }\end{array}$ & $939.55 \mathrm{~A}$ & $992.88 \mathrm{AB}$ & $966.22 \mathrm{AB}$ & $63.19 \mathrm{~B}$ & $69.06 \mathrm{~B}$ & $66.12 \mathrm{~B}$ & $6.82 \mathrm{~B}$ & $6.99 \mathrm{~B}$ & $6.90 \mathrm{~B}$ \\
\hline F.test & NS & $*$ & $*$ & $*$ & $*$ & $*$ & $*$ & $*$ & $*$ \\
\hline \multicolumn{10}{|c|}{ Hill spacing (Plants/fad) } \\
\hline $15 \mathrm{~cm}(46666)$ & $911.83 \mathrm{C}$ & $968.58 \mathrm{C}$ & $940.20 \mathrm{C}$ & $57.40 \mathrm{C}$ & $63.12 \mathrm{C}$ & $60.25 \mathrm{C}$ & $6.33 \mathrm{C}$ & $6.53 \mathrm{C}$ & $6.42 \mathrm{C}$ \\
\hline $20 \mathrm{~cm}(35000)$ & $946.08 \mathrm{~B}$ & $1003.33 \mathrm{~B}$ & $974.70 \mathrm{~B}$ & $63.25 \mathrm{~B}$ & $69.93 \mathrm{~B}$ & $66.58 \mathrm{~B}$ & $6.70 \mathrm{~B}$ & $6.92 \mathrm{~B}$ & $6.81 \mathrm{~B}$ \\
\hline $25 \mathrm{~cm}(28000)$ & $975.00 \mathrm{~A}$ & $1042.58 \mathrm{~A}$ & $1008.78 \mathrm{~A}$ & $67.91 \mathrm{~A}$ & $75.27 \mathrm{~A}$ & $71.59 \mathrm{~A}$ & $6.95 \mathrm{~A}$ & $7.19 \mathrm{~A}$ & $7.06 \mathrm{~A}$ \\
\hline F.test & $*$ & $*$ & $*$ & $*$ & $*$ & $*$ & $*$ & $*$ & $*$ \\
\hline NxD & $*$ & * & * & $*$ & * & * & * & $*$ & * \\
\hline
\end{tabular}




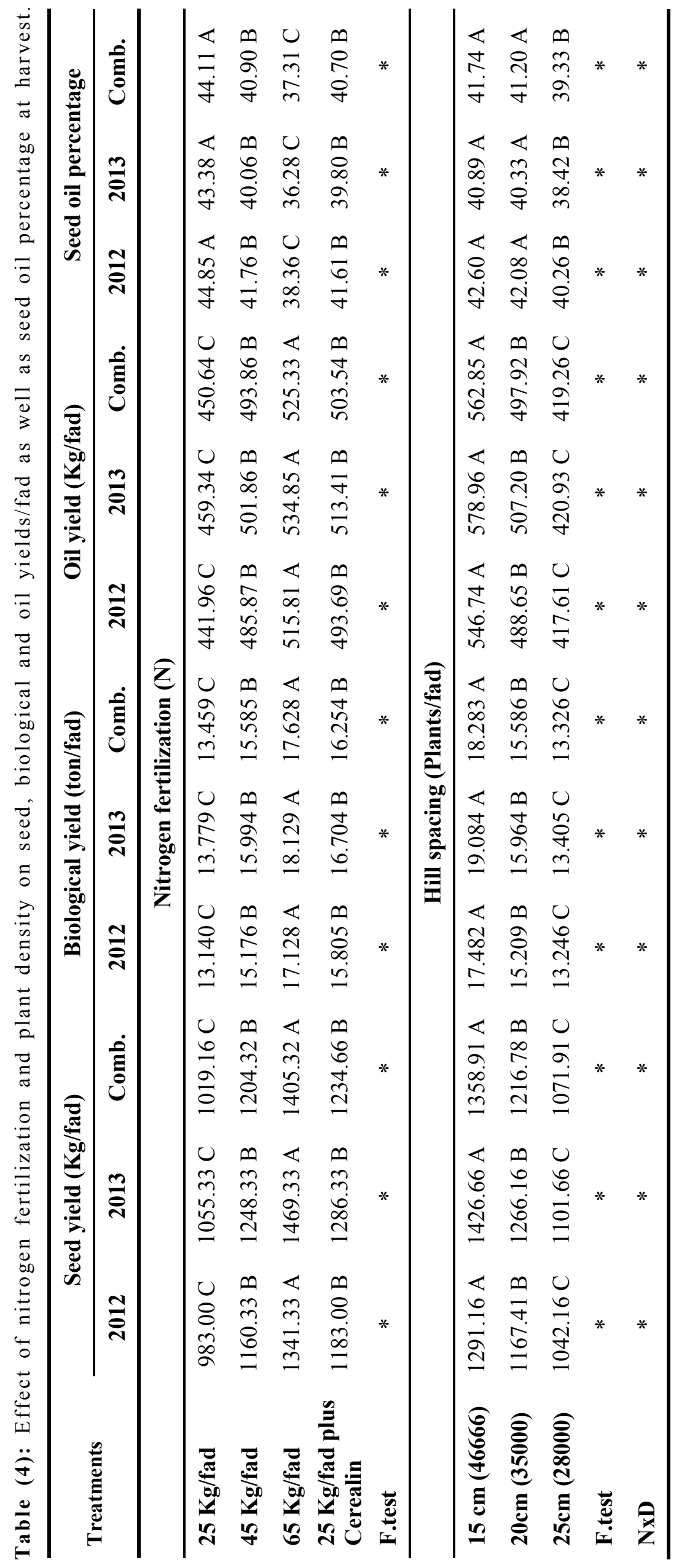


Table (5): Effect of the interaction between nitrogen fertilization and plant density on seed oil percentage as well as seed, biological and oil yields/fad (the combined data)

\begin{tabular}{|c|c|c|c|c|c|c|c|c|}
\hline \multirow{2}{*}{$\begin{array}{l}\text { Hill spacing } \\
\text { (Plants/fad) }\end{array}$} & \multicolumn{4}{|c|}{$\mathrm{N}$ fertilization (Kg N/fad) } & \multicolumn{4}{|c|}{$\mathrm{N}$ fertilization (Kg N/fad) } \\
\hline & 25 & 45 & 65 & $25+$ Cerealin & 25 & 45 & 65 & $25+$ erealin \\
\hline & \multicolumn{4}{|c|}{ Seed oil percentage } & \multicolumn{4}{|c|}{ Seed yield (Kg/fad) } \\
\hline $15 \mathrm{~cm}(46666)$ & 45.31 & 41.89 & 38.11 & 41.64 & 1118.66 & 1354.16 & 1584.66 & 1378.16 \\
\hline $20 \mathrm{~cm}(35000)$ & 44.66 & 41.34 & 37.68 & 41.12 & 1024.66 & 1208.16 & 1407.66 & 1226.66 \\
\hline $25 \mathrm{~cm}(28000)$ & 42.36 & 39.47 & 36.16 & 39.35 & 914.16 & 1050.66 & 1223.66 & 1099.16 \\
\hline LSD 0.05 & & & 1.84 & & & & 66 & \\
\hline \multirow{3}{*}{$\begin{array}{l}\text { Hill spacing } \\
\text { (Plants/fad) }\end{array}$} & \multicolumn{4}{|c|}{$\mathrm{N}$ fertilization (Kg N/fad) } & \multicolumn{4}{|c|}{$\mathrm{N}$ fertilization $(\mathrm{Kg} \mathrm{N} / \mathbf{f a d})$} \\
\hline & 25 & 45 & 65 & $25+$ Cerealin & 25 & 45 & 65 & $25+$ erealin \\
\hline & \multicolumn{4}{|c|}{ Biological yield (ton/ fad) } & \multicolumn{4}{|c|}{ Oil yield (Kg/fad) } \\
\hline $15 \mathrm{~cm}(46666)$ & 15.304 & 18.100 & 20.771 & 18.957 & 506.93 & 567.17 & 603.38 & 573.92 \\
\hline $20 \mathrm{~cm}(35000)$ & 13.469 & 15.641 & 17.257 & 15.980 & 457.63 & 499.51 & 530.13 & 504.42 \\
\hline $25 \mathrm{~cm}(28000)$ & 11.606 & 13.014 & 14.857 & 13.826 & 387.37 & 414.91 & 442.48 & 432.30 \\
\hline LSD 0.05 & \multicolumn{4}{|c|}{0.547} & \multicolumn{4}{|c|}{15.83} \\
\hline
\end{tabular}

\section{REFERANCES}

Abd El-Samie, F.S.; El-Bially, M.E. and Mahfouz, H. (1995). Influence of hand-hoeing and plant spacing on productivity of two sunflower varieties and accompanied weeds. Agric Sci. Mansoura Univ., 20 (6):2673-2681.

Abd El-Samie, F. S.; Shams, S. A. A. and El-Khalil, H. El. A. (2002). Effect of plant densities and nitrogen levels on yield and yield components of sunflower. Ann. Agric., Sci. Moshtohor, 40(4):2005-2014.

Abou-Khadrah, S. H.; Mohamed, A. A. E.; Gerges, N. R. and Diab, Z. M. (2002).Response of four sunflower hybrids to low nitrogen fertilizer levels and Phosphorine biofertilizer. J. Agric. Res., Tanta Univ., 28(1):105-118.

Abou-Khadrah, S.H.; Mohamed, A.A.E.; Tabl, M.A. and Demian, K. R. (2000). Effect of nitrogen fertilization on growth and yield of some sunflower cultivars grown in calcareous soil. Proc. $9^{\text {th }}$ conf. Agron., Minufiya Univ.,1-2 Sept. 2000 :483-493.

Akbari, P.; Ghalavand, A.; Modarres Sanavy, A.M. and Alikhani, M.A. (2011).The effect of biofertilizers, nitrogen fertilizer and farmyard manure on grain yield and seed quality of sunflower (Helianthus annuus L.). J. Agric. Tech., 7(1):173-184.

Al-Doori, S. A. M. A. (2012). Effect of plant densities on growth, yield components and quality of some sunflower cultivars (Helianthus annuus L.). College of Basic Education Res. J., 12(2):765-776.

Ali, A. and Noorka, I. R. (2013). Nitrogen and phosphorus management strategy for better growth and yield of sunflower (Helianthus annuus L.) hybrid. Soil Environ. 32(1): 44-48

Ali, A.; Ahmad, A.; Khaliq, T.; Afzal, M. and Iqbal, Z. (2012). Achene yield and quality response of sunflower hybrids to nitrogen at varying planting densities. Int. Conf. Agric. Chemical and Env. Sci. (oct.6-7, 2012):73-77.

Ali, H.; Randhawa, S.A. and Yousaf, M. (2004). Quantitative and qualitative traits of sunflower (Helianthus annuus L.) as influenced by planting dates and nitrogen application. Int. J. Agric. Biol., $6(2): 410-412$.

Allam, A.Y. and Galal A. H. (1996). Effect of nitrogen fertilization and plant density on yield and quality of sunflower. Assi. J. Agric. Sci., 27(2):169-177.

A.O.A.C. (1975). Official Methods of Analysis. $12^{\text {th }}$ Ed. Assoc. Official Agric. Chem., Washington, D.C.

Al-Thabet, S.S. (2006). Effect of plant spacing and nitrogen levels on growth and yield of sunflower (Helianthus annuus L.). J. King Saud Univ., 19, Agric. Sci. (1):1-11.

Aowad, M. M. and Mohamed, A. A. A. (2009). The effect of bio, organic and mineral fertilization on productivity of sunflower seed and oil yields. J. Agric. Res. Kafrelsheikh Univ., 35(4):1013-1028.

Basha, H.A. (2000). Response of two sunflower cultivars to hill spacings and nitrogen fertilizer levels under sandy soil conditions. Zagazig J. Agric. Res., 27(3):617-633.

Bassal, S. A. A. (2003). Impact of tillage systems, hill spacings and bio and chemical phosphatic fertilization regimes on yield and its components of sunflower (Helianthus annuus L.). Zagazig J. Agric. Res., 30(3):619- 634.

Beg, A.; Pourdad, S. S. and Alipour, S. (2007). Row and plant spacing effects on agronomic performance of sunflower in warm and semi-cold areas of Iran. Helia, 30(47):99-104.

Bukhsh, M. A. A. H. A.; Ishaque, S. K. M.; Iqbal, J.; Randhawa, M. A.; Rasheed M. and Khan, H. A. (2011). Morphological features in sunflower as influenced by varying nutritional area. Pak. J. Nutr., 10(5):470-474. 
Duncan, D. B. (1955). Multiple Range and Multiple "F" Tests. Biometrics, 11:1- 24.

El-Kalla, S. E.; Sharief, A. E.; Ghoenema, M. H. and El-Saidy A. A. (1998). Response of some sunflower hybrids to NPK fertilizer rates and yield analysis. Proc. $8^{\text {th }}$ Conf. Agron., Suez Canal Univ., Ismailia, Egypt, 28-29 Nov., 535-543.

El-Naim, A. M. and Ahmed. M. F. (2010). Effect of irrigation intervals and inter-row spacing on the vegetative growth characteristics in sunflower (Helianthus annuus L.) hybrids in shambat soil. J. Appl. Sci. Res., 6(9):1440-1445.

El-Sarag, E. I. (2007). Influence of plant population and nitrogen fertilization levels on performance of some sunflower cultivars under North Sinai conditions. Ann. Agric. Sci., Ain Shams Univ., 25(1):113-121.

Geweifel, H. G. M; Osman, F, A. A.; and El-Banna, A.Y. (1997). Response of sunflower to phosphorus and nitrogen fertilization under different plant densities in sandy soil. Zagazig J. Agric. Res., 24(3):435- 448

Gholinezhad, E.; Aynaband, A.; Ghorthapeh, A.H.; Noormohamadi, G. and Bernousi, I. (2009). Study of the effect of drought stress on yield, yield components and harvest index of sunflower hybrid Iroflor at different levels of nitrogen and plant population. Not. Bot. Hort. Agrobot. Cluj, 37(2):85-94.

Hassan, T. H. A. (2007).Effect of some cultural treatments on sunflower in north Sinai. M.Sc. Thesis, Dept. Plant Production, Fac. Environ. Agric. Sci., El- Arish Univ.

Hassan, T. H. A. (2010). Bio and mineral fertilization studies on sunflower under north Sinai conditions. $\mathrm{Ph}$. D. Thesis, Dept. Plant Production, Fac. Environ. Agric. Sci., El-Arish Univ.

Ibrahim, M. E.; Abd El-Ghany, H. M. and Gaafar, N. A. (2006). Effect of nitrogen fertilizer and its application time on growth and yield of two sunflower varieties. Bull. NRC. Egypt, 31(3):233243.

Ibrahim, M. E.; El-Absawy, E. A.; Selim, A. H. and Gaafar, N. A. (2003). Effect of nitrogen and phosphorus fertilization levels on growth, photosynthetic pigments, yield and yield attributes of some sunflower varieties (Helianthus annuus, L.). Zagazig J. Agric. Res., 30(4):1223- 1271

Keshta, M. M. and El-Kholy, M. H. (1999). Effect of inoculation with $\mathrm{N}_{2^{-}}$fixing bacteria, nitrogen fertilizer and organic manure on sunflower. Proc.of the Int. Symposium on Biological Nitrogen Fixation and Crop Production, 11-13 May, 181187, ARC.

Khalil, H. E. (2003). Response of sunflower to different preceding crops and nitrogen fertilizer levels. Minufia J. Agric. Res., 28(6):1899-1913.

Malik, M. A.; Shah, S. H.; Mahmood, S. and Cheema, M. A. (2001) Effect of various planting geometries on the growth, seed yield and oil content of new sunflower hybrid (SF-187) .Int. J. Agric. Biol., 3(1):55-56.
Marschner, H. (1986). Mineral nutrition of higher plants. Academic press INC, U.S.A., 674 pp.

Mehrpouyan, M.; Nazari-Golshan, A. and Sayfzadea, S. (2010). Effect of irrigation stop at different growth stages on some agronomic traits of sunflower (Helianthus annuus) under three plant densities in Takestan Region, Iran. Plant Ecophysiology, 2: 137-144.

Metwally, I. O. S. (1997). Growth and yield of sunflower as affected by preceding winter crops, $\mathrm{N}$-fertilizer levels and plant population. J. Agric. Sci. Mansoura Univ., 22 (9): 2769-2777.

Mohamed, A. A. E. (2003). Response of sunflower to Phosphorine and Cerealin inoculation under low NP-fertilizer levels. J. Agric. Res., Tanta Univ., 29(2):236-249.

Mostafa, G. G. and Abo-Baker, A. A. (2010). Effect of bio- and chemical fertilization on growth of sunflower (Helianthus annuus, L.) at south valley area. Asian J. crop science, 2(3):137-146.

Namvar, A.; Khandan, T. and Shojaei, M. (2012). Effects of bio and chemical nitrogen fertilizer on grain and oil yield of sunflower (Helianthus annuus L.) under different rates of plant density. Ann. Biol. Res., 3(2):1125-1131.

Olowe, V. I. O. (2005). Effect of plant population density on growth and yield of sunflower (Helianthus annuus L.) in the transition zone of south west Nigeria. Tropical Agric. Res. Extension, 8:37-44.

Patra, P.; Pati, B. K.; Ghosh, G. K.; Mura, S. S. and Saha, A. (2013). Effect of biofertilizers and sulphur on growth, yield, and oil content of hybrid sunflower (Helianthus annuus, L.) in a typical lateritic soil. Open Access Scientific Reports, 2(1):1-5.

Rhoads, F. M. and Bloodworth, A. H. (1964). Area measurements of cotton leaves by a dry weight methods. Agron. J., 56:520

Sala, F.; Radulov, I.; Crista, F. and Berbecea, A. (2010).The correlation between the fertilization system and yield for the sunflower crop. Res. J. Agric. Sci., 42(3):296-301.

Sarhan, A. A. (1995).Varietal response to plant spacing in sunflower under sandy soil conditions. Zagazig J. Agric. Res., 22(1):11-30

Sharief, A. E. and Said, EL. M. (1993). The contribution of sowing dates, plant density on the productivity of some oil seed sunflower cultivars. J. Agric. Sci. Mansoura Univ., 18(4):959-967.

Shehata, M. M. and EL-Khawas, S. A. (2003). Effect of two biofertilizers on growth parameters, yield characters, nitrogenous components, nucleic acids content, minerals, oil content, protein profiles and DNA banding pattern of sunflower (Helianthus annuus, L. cv.Vedock) yield. Pak. J. Biol. Sci., 6(14):1257-1268.

Sincik, M.; Goksoy, A. T. and Dogan, R. (2013). Responses of sunfower (Helianthus annuus L.) to irrigation and nitrogen fertilization rates. Zemdirbyste-Agriculture, 100(2):151-158 
Snedecor, W. G. and Cochran, W. G. (1982). Statistical Methods. $7^{\text {th }}$ Ed. $2^{\text {nd }}$ printing, Iowa State Univ., Ames. Iowa, USA, $507 \mathrm{pp}$.

Soleimanzadeh, H.; Habibi, D.; Ardakani, M. R.; Paknejad, F. and Rejali, F. (2010). Response of sunflower (Helianthus annuus, L.) to inoculation with Azotobacter under different nitrogen levels. American-Eurasian J. Agric. \& Environ. Sci., $7(3): 265-268$.

Wabekwa, J. W.; Degri, M. M. and Dangari, L. C. (2012).The effects of nitrogen mineral on yield performance of sunflower (Helianthus annuus, L.) in bauchi state, Nigeria. J. Envir. Iss. Agric. In Devel. Count, 4(3): 56- 61.

Yasein, M. A. E-S. T. (2010). Some agronomic factors affecting productivity and quality of sunflower crop (Helianthus annuus, L.). Ph. D. Thesis, Dept. Agron. Fac. Agric., Zagazig Univ.

Zeiton, O. A. A. (1992). Response of sunflower (Helianthus annuus, L.) to planting density and levels of $\mathrm{N}$ fertilization. Zagazig J. Agric. Res., 19(4):1535-1566.

$$
\begin{aligned}
& \text { استجابة عباد الثمس للتسميد الازوتى والكثافة النباتية في الاراضى الرملية }
\end{aligned}
$$

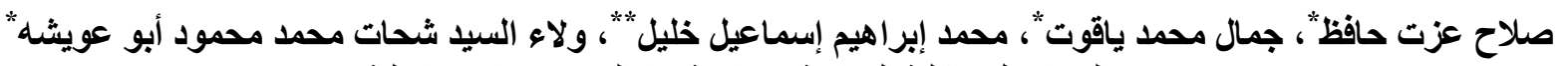

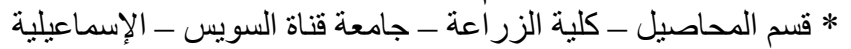

$$
\begin{aligned}
& \text { ** قسم النبات الزر اعى - كلية الزر اعة - جامعة قناة السويس - الإسماعيلية }
\end{aligned}
$$

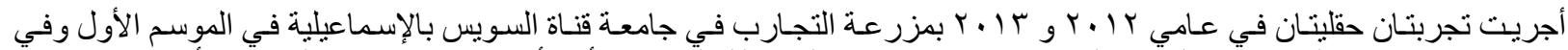

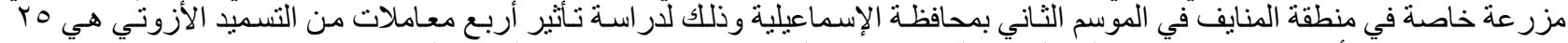

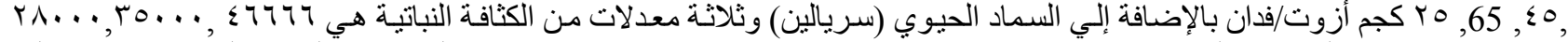

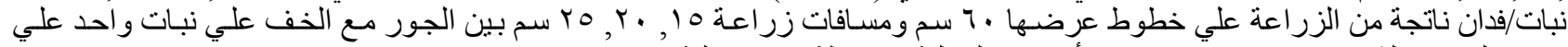

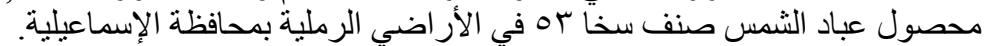

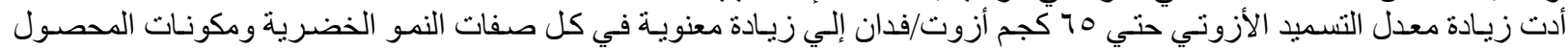

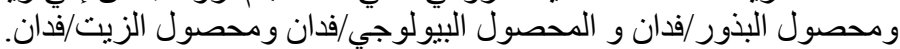

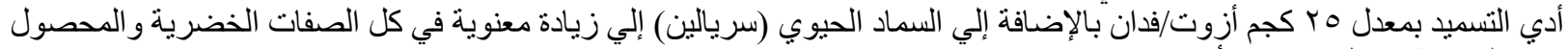

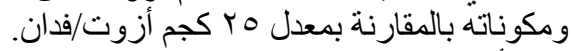

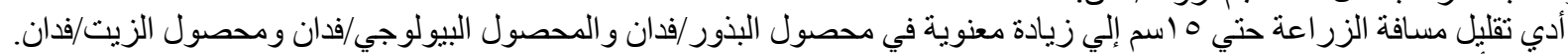

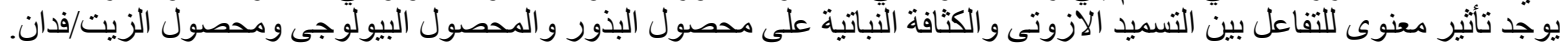

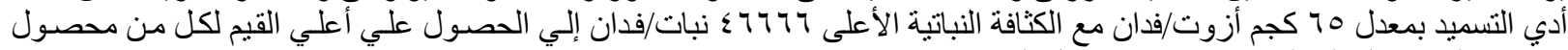

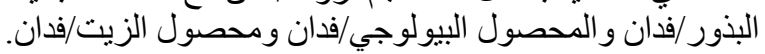

$$
\begin{aligned}
& \text { الكلمات الدالةه: عباد الثمس ـ التسميد الأزوتي ـ التسميد الحيوي ـ الكثافه النباتية. }
\end{aligned}
$$

